\title{
Effect of Annealing Temperature on $\mathrm{CuInSe}_{2} / \mathrm{ZnS}$ Thin-Film Solar Cells Fabricated by Using Electron Beam Evaporation
}

\author{
H. Abdullah and S. Habibi \\ Department of Electrical, Electronics, and Systems Engineering, Faculty of Engineering and Built Environment, \\ Universiti Kebangsaan Malaysia, 43600 Bangi, Selangor, Malaysia
}

Correspondence should be addressed to H. Abdullah; huda@eng.ukm.my

Received 17 October 2012; Accepted 10 December 2012

Academic Editor: Sudhakar Shet

Copyright ( 2013 H. Abdullah and S. Habibi. This is an open access article distributed under the Creative Commons Attribution License, which permits unrestricted use, distribution, and reproduction in any medium, provided the original work is properly cited.

$\mathrm{CuInSe}_{2}$ (CIS) thin films are successfully prepared by electron beam evaporation. Pure $\mathrm{Cu}$, In, and Se powders were mixed and ground in a grinder and made into a pellet. The pallets were deposited via electron beam evaporation on FTO substrates and were varied by varying the annealing temperatures, at room temperature, $250^{\circ} \mathrm{C}, 300^{\circ} \mathrm{C}$, and $350^{\circ} \mathrm{C}$. Samples were analysed by $\mathrm{X}$-ray diffractometry (XRD) for crystallinity and field-emission scanning electron microscopy (FESEM) for grain size and thickness. I-V measurements were used to measure the efficiency of the CuInSe $e_{2} / \mathrm{ZnS}$ solar cells. XRD results show that the crystallinity of the films improved as the temperature was increased. The temperature dependence of crystallinity indicates polycrystalline behaviour

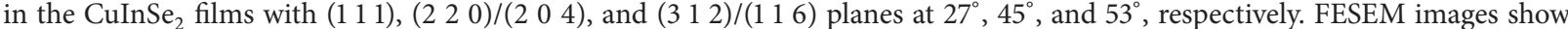
the homogeneity of the CuInSe ${ }_{2}$ formed. I-V measurements indicated that higher annealing temperatures increase the efficiency of $\mathrm{CuInSe}_{2}$ solar cells from approximately $0.99 \%$ for the as-deposited films to $1.12 \%$ for the annealed films. Hence, we can conclude that the overall cell performance is strongly dependent on the annealing temperature.

\section{Introduction}

Among various materials for thin film solar cells, copper indium diselenide $\left(\mathrm{CuInSe}_{2}\right)$ has emerged as a promising material due to its use as a solar radiation absorber. In recent years, interest has increased regarding the use of copper indium selenide (CIS) compounds, which are elements of the I-III-VI 2 group, as materials for thin film photovoltaic solar cells because of their high theoretical efficiency of approximately $24.8 \%$ [1]. $\mathrm{CuInSe}_{2}$ is a promising material for thin film solar cells because of its extraordinary radiation stability [2]. CuInSe ${ }_{2}$ films possess certain exceptional material characteristics including a band-gap, absorption coefficient and minority carrier diffusion length which are particularly suitable for photovoltaic applications. Because these films can be prepared with n- and p-type conductivity, there is potential for both a homo- and heterojunction [3]. CuInSe is also favoured because it is more environmentally benign than CIS. These materials have remarkably stable electrical properties over a wide range of stoichiometries [4]. Recently, CIS solar cells have been produced with efficiencies as high as $15.4 \%$, and have demonstrated good long-term stability and stable device performance [5]. To achieve further commercial success for CuInSe $e_{2}$-based photovoltaics and to reduce the cost of these solar cells, it is necessary to mass-produce quality $\mathrm{CuInSe}_{2}$ films via a low-cost, eco-friendly, and easily scalable process [6]. Evaporation techniques are typically used to produce good film stoichiometry for elements and simple compounds [7]. Among II-VI compounds, zinc sulfide (ZnS) and zinc selenide ( $\mathrm{ZnSe}$ ) are suitable for many applications [8]. ZnS has a large band gap of approximately $3.7 \mathrm{eV}$, high refractive index, high precision dielectric constant, and broad band of wavelengths [9]. At certain temperatures, $\mathrm{ZnS}$ can change phase from cubic to wurtzite [10]. ZnS can be used in the fabrication of optoelectronic devices, photoconductors and window materials for thin film heterojunction solar cells [11]. The aim of this research is to study the dependence of $\mathrm{CuInSe}_{2}: \mathrm{ZnS}$ solar cell efficiencies, structures, and morphologies on the annealing temperature of the $\mathrm{CuInSe}_{2}$ films. In this study, $\mathrm{CuInSe}_{2}$ films with an annealing temperature of room temperature $\left(27^{\circ} \mathrm{C}\right), 250^{\circ} \mathrm{C}, 300^{\circ} \mathrm{C}$, or $350^{\circ} \mathrm{C}$ were examined for changes in morphology and structure by 


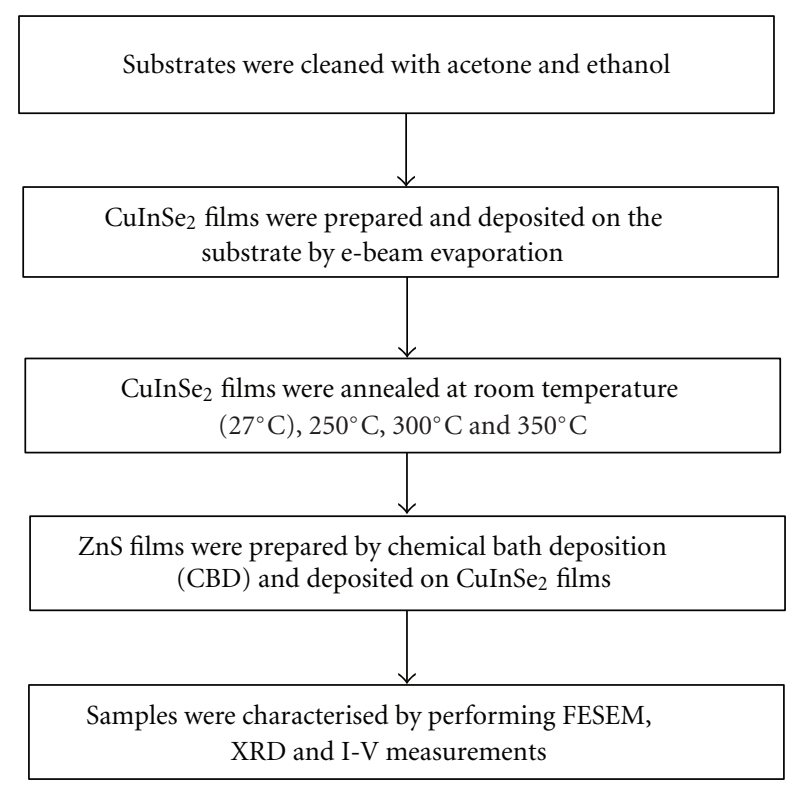

FIGURE 1: Flow chart of overall process in fabrication of $\mathrm{CuInSe}_{2}: \mathrm{ZnS}$ solar cell by electron beam evaporation and chemical bath deposition (CBD) method.

FESEM and XRD analysis. To study the effects of the annealing temperature on the overall $\mathrm{CuInSe}_{2}: \mathrm{ZnS}$ solar cell efficiency, I-V measurements were performed for thin films with annealing temperatures of $27^{\circ} \mathrm{C}$ and $100^{\circ} \mathrm{C}$.

\section{Experimental Details}

$\mathrm{CuInSe}_{2}$ layers were produced by annealing CuInSe $\mathrm{C}_{2}$ pellets onto FTO glass substrates via electron beam evaporation. $\mathrm{ZnS}$ layers were made using the chemical bath deposition (CBD) technique with a $3 \mathrm{~h}$ deposition time. The CuInSe pellets were made from a mixture of $\mathrm{Cu}$, In and Se powders, while $\mathrm{ZnS}$ films were fabricated from a $\mathrm{Zn}\left(\mathrm{CH}_{3} \mathrm{COO}\right)_{2}$, TEA, $\mathrm{NH}_{3}, \mathrm{C}_{6} \mathrm{H}_{5} \mathrm{Na}_{3} \mathrm{O}_{7}$ and thiourea solution. CuInSe $\mathrm{C}_{2}$ films were varied by using annealing temperatures of room temperature, $250^{\circ} \mathrm{C}, 300^{\circ} \mathrm{C}$, and $350^{\circ} \mathrm{C}$ to study the effect of the annealing temperature on the morphology, structure and the efficiency of the solar cells. The flow of the cell fabrication is outlined in Figure 1. The surface morphology was studied with fieldemission scanning electron microscopy (FESEM) while the crystallinity of the CuInSe ${ }_{2}$ films was determined by Xray diffraction (XRD). I-V data were collected by Gamry Instruments G300 with a light intensity of $110 \mathrm{~mW} / \mathrm{cm}^{2}$. Figure 2 shows a diagram of the prepared samples with $\mathrm{ZnS}$ and $\mathrm{CuInSe}_{2}$ films on top of a glass substrate with an FTO layer.

\section{Results and Discussions}

Figure 2 shows the cross-section of prepared samples with $\mathrm{ZnS}$ and $\mathrm{CuInSe}_{2}$ films on top of glass substrate and FTO layer while Figure 3 shows FE-SEM images of $\mathrm{CuInSe}_{2}$ films deposited with an annealing temperature of $27^{\circ} \mathrm{C}, 250^{\circ} \mathrm{C}$,

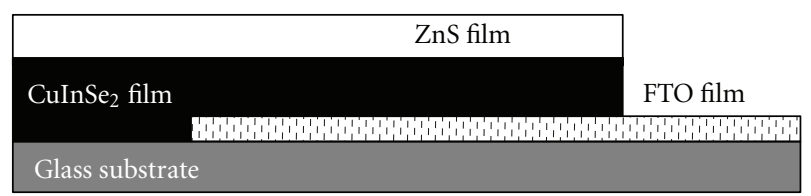

FIGURE 2: Cross-section of prepared samples with $\mathrm{ZnS}$ and $\mathrm{CuInSe}_{2}$ films.

TABLE 1: Particle size of $\mathrm{CuInS}_{2}$ for each annealing temperature.

\begin{tabular}{lc}
\hline Annealing temperature $\left({ }^{\circ} \mathrm{C}\right)$ & Particle size $(\mathrm{nm})$ \\
\hline 27 & 113.90 \\
250 & 27.90 \\
300 & 21.66 \\
350 & 24.03 \\
\hline
\end{tabular}

$300^{\circ} \mathrm{C}$, or $350^{\circ} \mathrm{C}$. From the results obtained, $\mathrm{CuInSe}_{2}$ films were deposited uniformly over the substrate. These layers covered the entire surface of the substrate even without annealing, but the nonannealed films resulted in grains having less homogeneity. The grains became smaller and more densely arranged when temperature increased from $300^{\circ} \mathrm{C}$ to $350^{\circ} \mathrm{C}$ than when the temperature was increased from $250^{\circ} \mathrm{C}$ to $300^{\circ} \mathrm{C}$. FE-SEM also shows an increase in grain size due to the roughness that developed when the growth rate was increased with an increase in annealing temperature [12]. The average particle size and film thicknesses are shown in Table 1.

As shown in Table 1, the average particle sizes were $156.33 \mathrm{~nm}, 137.70 \mathrm{~nm}, 139.53 \mathrm{~nm}$, and $163.77 \mathrm{~nm}$ for annealing temperatures of $27^{\circ} \mathrm{C}, 250^{\circ} \mathrm{C}, 300^{\circ} \mathrm{C}$, and $350^{\circ} \mathrm{C}$, respectively. After the heat treatment, single grains of $\mathrm{CuInSe}_{2}$ were developed and the morphology of the films became denser. The thicknesses measured $172.67 \mathrm{~nm}, 109.76 \mathrm{~nm}, 121.33 \mathrm{~nm}$, and $133.23 \mathrm{~nm}$ for the annealing temperatures of $27^{\circ} \mathrm{C}, 250^{\circ} \mathrm{C}$, $300^{\circ} \mathrm{C}$, and $350^{\circ} \mathrm{C}$, respectively. These show that at room temperature, $\mathrm{CuInSe} e_{2}$ films have the greatest thickness, and after annealing, the thickness decreases from $172.67 \mathrm{~nm}$ to $109.76 \mathrm{~nm}$. This thickness change occurs because the smaller grains deposited on the film upon thermal treatment have less energy and have lost some of the weak binding between the grains and the substrate. These grains leave the substrate after annealing, but with increased annealing temperatures up to $300^{\circ} \mathrm{C}$ and $350^{\circ} \mathrm{C}$, the denser grains become larger serve to increase the thickness of the film. The average size of the grains measured was approximately $100 \mathrm{~nm}$. The similar phenomenon has also been studied by Zhang et al. 2010 [13]. We can conclude from these results that annealing temperature, particle size and film morphology are all proportionally related.

The diffraction patterns for $\mathrm{CuInSe}_{2}$ samples annealed at temperatures of $27^{\circ} \mathrm{C}, 250^{\circ} \mathrm{C}, 300^{\circ} \mathrm{C}$, and $350^{\circ} \mathrm{C}$ are shown in Figure 4. From analysis of the XRD patterns, it was observed that the $\mathrm{CuInSe}_{2}$ crystallinity increased from amorphous structure to a polycrystalline structure as the annealing temperature increased. As shown in Figure 4, the CuInSe films are amorphous at room temperature. There are three 


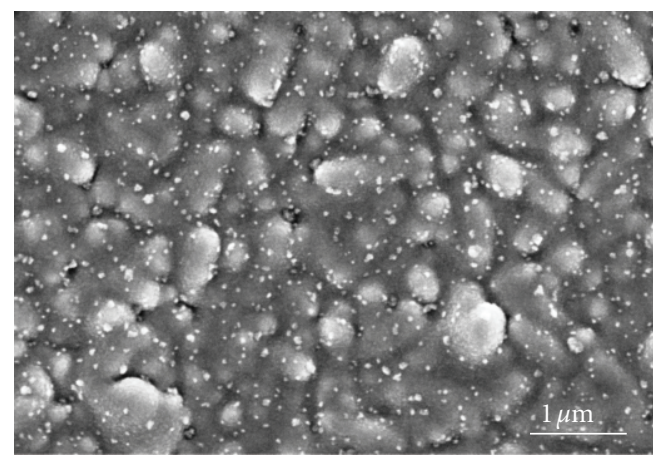

(a)

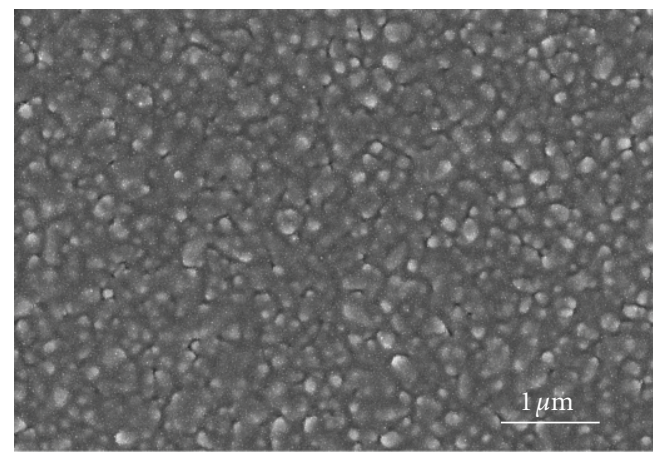

(c)

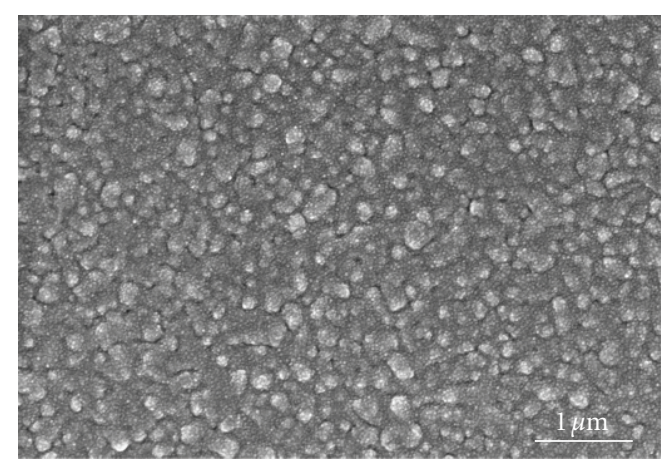

(b)

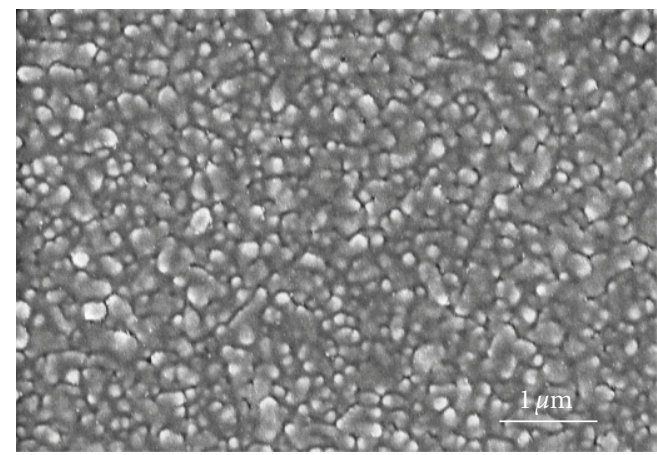

(d)

FIGURE 3: FESEM images of CIS samples prepared at temperature (a) room temperature, (b) $250^{\circ} \mathrm{C}$, (c) $300^{\circ} \mathrm{C}$, and (d) $350^{\circ} \mathrm{C}$.

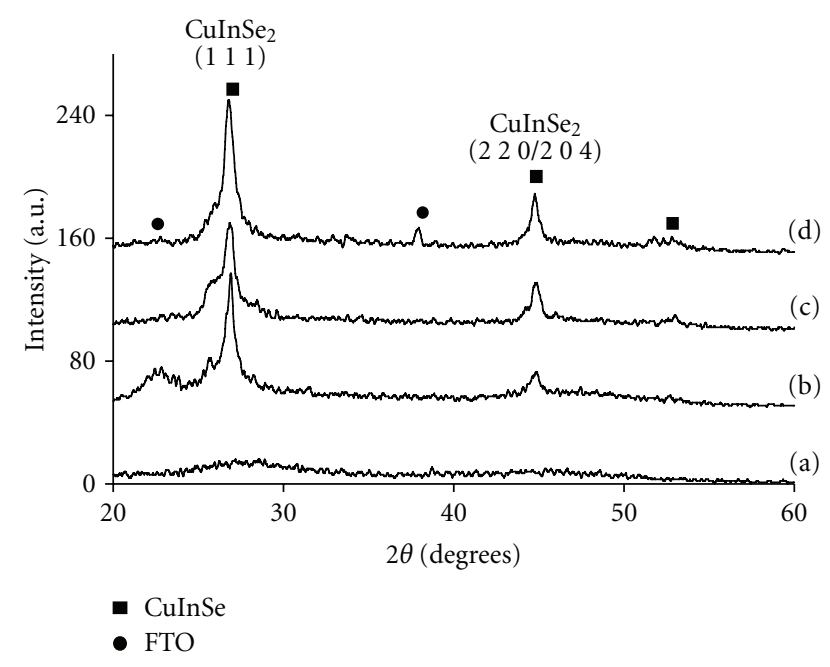

FIGURE 4: XRD results of CIS films prepared at temperature (a) room temperature, (b) $250^{\circ} \mathrm{C}$, (c) $300^{\circ} \mathrm{C}$, and (d) $350^{\circ} \mathrm{C}$.

dominant peaks corresponding to $\left(\begin{array}{lll}1 & 1 & 2\end{array}\right),\left(\begin{array}{lll}2 & 2 & 0\end{array}\right) /\left(\begin{array}{lll}2 & 0 & 4\end{array}\right)$, and $\left(\begin{array}{lll}3 & 1 & 2\end{array}\right) /\left(\begin{array}{lll}1 & 1 & 6\end{array}\right)$ orientations at a $2 \theta$ of $27^{\circ}, 45^{\circ}$, and $53^{\circ}$, respectively. These peaks have also been studied by Bindu et al. [6], Soon et al. [14], Yang and Chen [12], and Jeong et al. [15]. At an annealing temperature of $250^{\circ} \mathrm{C}$, three peaks, which contained both CuInSe $e_{2}$ and FTO, could be observed with (1 112$)$ and $\left(\begin{array}{lll}2 & 2 & 0\end{array}\right) /\left(\begin{array}{lll}2 & 0 & 4\end{array}\right)$ orientations, as reported by Bernéde and Assmann [16]. At a temperature of $300^{\circ} \mathrm{C}$,
$\mathrm{CuInSe}_{2}$ peaks were dominant and the FTO peaks slowly disappeared. When the temperature was increased to $350^{\circ} \mathrm{C}$, $\mathrm{CuInSe}_{2}$ peaks appeared at three locations $(2 \theta)$ of $27^{\circ}, 45^{\circ}$, and $53^{\circ}$. The peaks became sharper after the annealing temperature was increased, showing that the crystal sizes were larger than $1 \mathrm{~nm}$ [17]. The intensity of the peaks decreased with increasing annealing temperature, showing that the amount of the binary compound CuSe decreases during the annealing process. Higher and sharper peaks also appeared, showing that the primary crystal structure was successfully increased after the annealing process.

Figure 4 also shows that the main phase of the deposited $\mathrm{CuInSe}_{2}$ film has a chalcopyrite structure [18].

A qualitative estimation of the crystal size was obtained from Scherrer's formula:

$$
D=\frac{k \lambda}{B \cos \theta}
$$

where $k$ is the shape factor, $\lambda$ is the wavelength $(0.154 \mathrm{~nm}), B$ is the full-width at half-maximum of the main peak, and $\theta$ is the main peak position [19]. The crystal size was calculated and is shown in Table 2. The average crystal size of CuInSe $e_{2}$ was $2.63 \mathrm{~nm}, 2.55 \mathrm{~nm}$, and $3.05 \mathrm{~nm}$ for CuInSe $\left(\begin{array}{lll}1 & 1 & 1\end{array}\right)$, $8.99 \mathrm{~nm}, 7.49 \mathrm{~nm}$, and $7.05 \mathrm{~nm}$ for the $\left(\begin{array}{lll}2 & 2 & 0\end{array}\right) /\left(\begin{array}{lll}2 & 0 & 4\end{array}\right)$

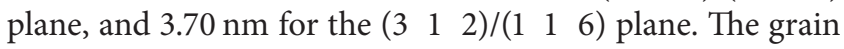
size increased in the $\left(\begin{array}{lll}1 & 1 & 1\end{array}\right)$ plane and decreased in the

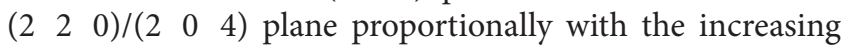
annealing temperature. At the higher temperatures of $300^{\circ} \mathrm{C}$ 
TABLE 2: Crystal size and diffraction angle for each of annealing temperature.

\begin{tabular}{|c|c|c|c|c|}
\hline Samples & Annealing temperature $\left({ }^{\circ} \mathrm{C}\right)$ & $2 \theta$ (degrees) & Crystal size, $d(\mathrm{~nm})$ & $(h k l)$ \\
\hline $\mathrm{CuInSe}_{2} 27$ & 25 & Amorphous & Amorphous & Amorphous \\
\hline \multirow{2}{*}{$\mathrm{CuInSe}_{2} 250$} & \multirow{2}{*}{250} & 26.9 & 2.63 & 111 \\
\hline & & 45.0 & 8.99 & $220 / 204$ \\
\hline \multirow{2}{*}{$\mathrm{CuInSe}_{2}-300$} & \multirow{2}{*}{300} & 26.9 & 2.55 & 111 \\
\hline & & 44.9 & 7.49 & $220 / 204$ \\
\hline \multirow{3}{*}{$\mathrm{CuInSe}_{2}-350$} & \multirow{3}{*}{350} & 26.8 & 3.05 & 112 \\
\hline & & 44.8 & 7.05 & $220 / 204$ \\
\hline & & 52.7 & 3.70 & $312 / 116$ \\
\hline
\end{tabular}

TABLE 3: Efficiency of CuInSe $e_{2}: \mathrm{ZnS}$ solar cell at produced room temperature and annealing temperature of $100^{\circ} \mathrm{C}$.

\begin{tabular}{lcccc}
\hline Sample & Annealing temperature $\left({ }^{\circ} \mathrm{C}\right)$ & Current density, $J\left(\mathrm{~mA} / \mathrm{cm}^{2}\right)$ & Open-circuit voltage $(\mathrm{V})$ & Fill factor FF Efficiency $(\%)$ \\
\hline 4000_room temperature & 27 & 8.65 & 0.20 & 0.36 \\
4000_100 & 100 & 1.92 & 1.96 & 0.99 \\
\hline
\end{tabular}

and $350^{\circ} \mathrm{C}$, the FTO peak disappeared and a peak corresponding to the $\left(\begin{array}{lll}3 & 1 & 2\end{array}\right) /\left(\begin{array}{lll}1 & 1 & 6\end{array}\right)$ plane is observed, showing that the growth of the ternary compound $\mathrm{CuInSe}_{2}$. This analysis shows that the crystalline structure of $\mathrm{CuInSe}_{2}$ films can be changed from an amorphous to a polycrystalline phase with heat treatment.

$\mathrm{CuInSe}_{2}: \mathrm{ZnS}$ solar cells were fabricated by depositing $\mathrm{ZnS}$ thin films on top of $\mathrm{CuInSe}_{2}$ films via the chemical bath deposition (CBD) method with a deposition time of $3 \mathrm{~h}$. Figure 5 shows the I-V curves for $\mathrm{CuInSe}_{2}: \mathrm{ZnS}$ solar cells for the CuInSe $e_{2}$ films annealed at temperatures of $27^{\circ} \mathrm{C}$ and $100^{\circ} \mathrm{C}$. These temperatures have been chosen for the I-V measurements and are merely included to study the effect of annealing treatments on the overall solar cell efficiency. As shown in Figure 5, the effect of the changes in annealing temperature on the solar cell efficiencies was analysed and the results indicate that there was a difference in current density $\left(J_{\text {sc }}\right)$ and open-circuit voltage $\left(V_{\text {oc }}\right)$ of the samples before and after annealing. After annealing, $J_{\mathrm{sc}}$, decreased from $8.65 \mathrm{~mA} / \mathrm{cm}^{2}$ to $1.92 \mathrm{~mA} / \mathrm{cm}^{2}$ while $V_{\mathrm{oc}}$, increased from $0.20 \mathrm{~V}$ to $1.96 \mathrm{~V}$. This could be due to the surface morphology of the samples prior to annealing as was shown by FESEM. This condition enhanced the electron-hole pair recombination rate in the film which affected the overall cell performance. The cell with the thicker layer had a lower efficiency, despite having greater photon absorption due to a simultaneous decrease in internal quantum efficiency [20]. As shown in Table 3, which presents the calculated efficiency along with $J_{\mathrm{sc}}$, the fill factor, FF and $V_{\mathrm{oc}}$, annealing increases the efficiency of $\mathrm{CuInSe}_{2}: \mathrm{ZnS}$ solar cells from $0.99 \%$ to $1.12 \%$.

\section{Conclusions}

This study used electron beam evaporation, with annealing temperatures of $27^{\circ} \mathrm{C}, 250^{\circ} \mathrm{C}, 300^{\circ} \mathrm{C}$, and $350^{\circ} \mathrm{C}$, and the

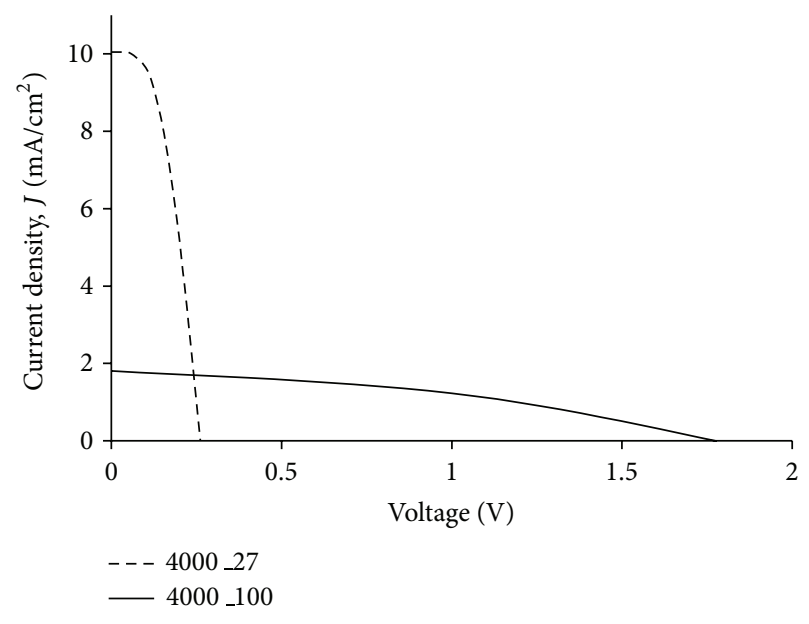

FIGURE 5: I-V measurement CIS : ZnS solar cell with room temperature $\left(27^{\circ} \mathrm{C}\right)$ and $100^{\circ} \mathrm{C}$.

chemical bath deposition (CBD) method, with a $3 \mathrm{~h}$ deposition time, to produce $\mathrm{CuInSe}_{2}: \mathrm{ZnS}$ solar cells. XRD analysis suggested that the diffraction of $\mathrm{CuInSe}_{2}$ films changed from an amorphous to a polycrystalline phase after annealing at $27^{\circ}, 45^{\circ}$ and $53^{\circ}$ at $\left(\begin{array}{lll}1 & 1 & 2\end{array}\right),\left(\begin{array}{lll}2 & 2 & 0\end{array}\right) /\left(\begin{array}{lll}2 & 0 & 4\end{array}\right)$, and $\left(\begin{array}{lll}3 & 1 & 2\end{array}\right) /\left(\begin{array}{lll}1 & 1 & 6\end{array}\right)$ orientations, respectively. FESEM results showed that the CuInSe ${ }_{2}$ particles were in better arrays after annealing and had sizes of $156.33 \mathrm{~nm}, 137.70 \mathrm{~nm}, 139.53 \mathrm{~nm}$, and $163.77 \mathrm{~nm}$. The thicknesses measured were $172.67 \mathrm{~nm}$, $109.76 \mathrm{~nm}, 121.33 \mathrm{~nm}$, and $133.23 \mathrm{~nm}$ for annealing temperatures of $27^{\circ} \mathrm{C}, 250^{\circ} \mathrm{C}, 300^{\circ} \mathrm{C}$, and $350^{\circ} \mathrm{C}$, respectively. From these data, we conclude that as the annealing temperature increases, the particle size and thickness also increase. I$\mathrm{V}$ measurements indicated that annealing increases the efficiency of solar cells from $0.99 \%$ to $1.12 \%$. These results show the dependence of both the efficiency and the structural and 
morphological characteristics of $\mathrm{CuInSe}_{2}$ layers on annealing temperature.

\section{References}

[1] O. Tesson, M. Morsli, A. Bonnet, V. Jousseaume, L. Cattin, and G. Massé, "Electrical characterisation of $\mathrm{CuInSe}_{2}$ thin films for solar cells applications," Optical Materials, vol. 9, no. 1-4, pp. 511-515, 1998.

[2] A. V. Postnikov and M. V. Yakushev, "Lattice dynamics and stability of CuInSe ${ }_{2}$," Thin Solid Films, vol. 451-452, pp. 141-144, 2004.

[3] K. L. Chopra and S. R. Das, Thin Film Solar Cells, Plenum Press, New York, NY, USA, 1983.

[4] M. Altosaar, M. Danilson, M. Kauk et al., "Further developments in CIS monograin layer solar cells technology," Solar Energy Materials and Solar Cells, vol. 87, no. 1-4, pp. 25-32, 2005.

[5] T. Markvart and L. Castaner, Practical Handbook of Photovoltaics: Fundamentals and Applications, Elsevier, 2003.

[6] K. Bindu, C. S. Kartha, K. P. Vijayakumar, T. Abe, and Y. Kashiwaba, "CuInSe ${ }_{2}$ thin film preparation through a new selenisation process using chemical bath deposited selenium," Solar Energy Materials and Solar Cells, vol. 79, no. 1, pp. 67-79, 2003.

[7] A. Y. Ono, Electroluminescent Displays, World Scientific, Technology \& Engineering, 1995.

[8] P. Roy, J. R. Ota, and S. K. Srivastava, "Crystalline ZnS thin films by chemical bath deposition method and its characterization," Thin Solid Films, vol. 515, no. 4, pp. 1912-1917, 2006.

[9] A. U. Ubale, V. S. Sangawar, and D. K. Kulkarni, "Size dependent optical characteristics of chemically deposited nanostructured $\mathrm{ZnS}$ thin films," Bulletin of Materials Science, vol. 30, no. 2, pp. 147-151, 2007.

[10] D. Moore and W. L. Zhong, "Growth of anisotropic onedimensional ZnS nanostructures," Journal of Materials Chemistry, vol. 16, pp. 3898-3905, 2006.

[11] X. D. Gao, X. M. Li, and W. D. Yu, "Morphology and optical properties of amorphous ZnS films deposited by ultrasonicassisted successive ionic layer adsorption and reaction method," Thin Solid Films, vol. 468, no. 1-2, pp. 43-47, 2004.

[12] Y. H. Yang and Y. T. Chen, "Solvothermal preparation and spectroscopic characterization of copper indium diselenide nanorods," Journal of Physical Chemistry B, vol. 110, no. 35, pp. 17370-17374, 2006.

[13] Z. Zhang, J. Li, M. Wang, M. Wei, G. Jiang, and C. Zhu, "Influence of annealing conditions on the structure and compositions of electrodeposited CuInSe $\mathrm{e}_{2}$ films," Solid State Communications, vol. 150, no. 47-48, pp. 2346-2349, 2010.

[14] S. H. Kang, Y. K. Kim, D. S. Choi, and Y. E. Sung, "Characterization of electrodeposited CuInSe $e_{2}$ (CIS) film," Electrochimica Acta, vol. 51, no. 21, pp. 4433-4438, 2006.

[15] W. J. Jeong, H. G. Ahn, Y. J. Kim, H. H. Yang, and G. C. Park, "The properties of $\mathrm{CuInSe}_{2}$ by $\mathrm{DC} / \mathrm{RF}$ magnetron sputtering and thermal evaporation method," Transactions on Electrical and Electronic Materials, vol. 8, no. 2, pp. 89-92, 2007.

[16] J. C. Bernède and L. Assmann, "Polycrystalline CuInSe ${ }_{2}$ thin films synthesized by microwave irradiation," Vacuum, vol. 59, no. 4, pp. 885-893, 2000.

[17] E. Tzvetkova, N. Stratieva, M. Ganchev, I. Tomov, K. Ivanova, and K. Kochev, "Preparation and structure of annealed CuInSe ${ }_{2}$ electrodeposited films," Thin Solid Films, vol. 311, no. 1-2, pp. 101$106,1997$.

[18] Z. W. Zhang, J. Li, J. L. Liu, and C. F. Zhu, "Synthesis and characterization of supported $\mathrm{CuInSe}_{2}$ nanorod arrays on rigid substrates," Chinese Journal of Chemical Physics, vol. 24, no. 1, pp. 115-120, 2011.

[19] Z. H. Li, E. S. Cho, and S. J. Kwon, "Properties of the $\mathrm{Cu}(\mathrm{In}, \mathrm{Ga}) \mathrm{Se}_{2}$ absorbers deposited by electron-beam evaporation method for solar cells," Current Applied Physics, vol. 11, no. 1, pp. 28-33, 2011.

[20] V. A. Akhavan, M. G. Panthani, B. W. Goodfellow, D. K. Reid, and B. A. Korgel, "Thickness-limited performance of CuInSe ${ }_{2}$ nanocrystal photovoltaic devices," Optics Express, vol. 18, no. 19, pp. A411-A420, 2010. 

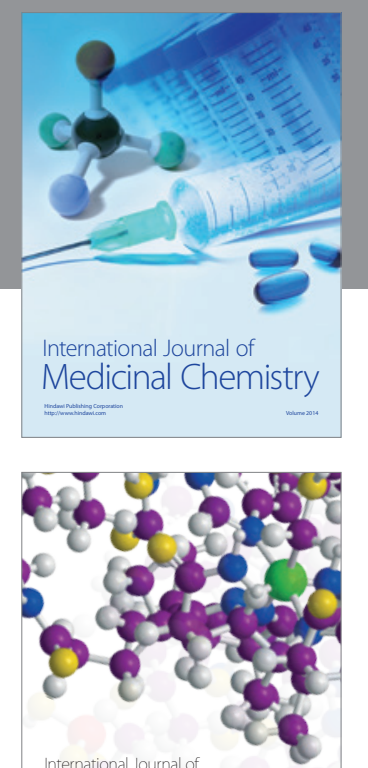

\section{Carbohydrate} Chemistry

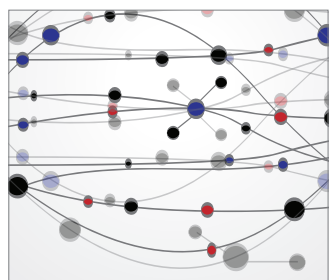

The Scientific World Journal
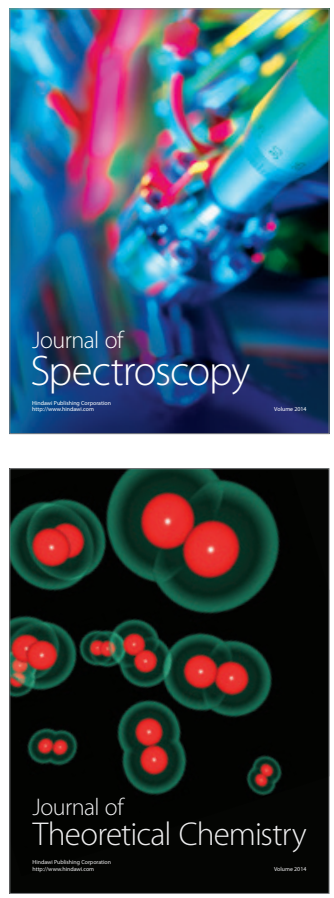
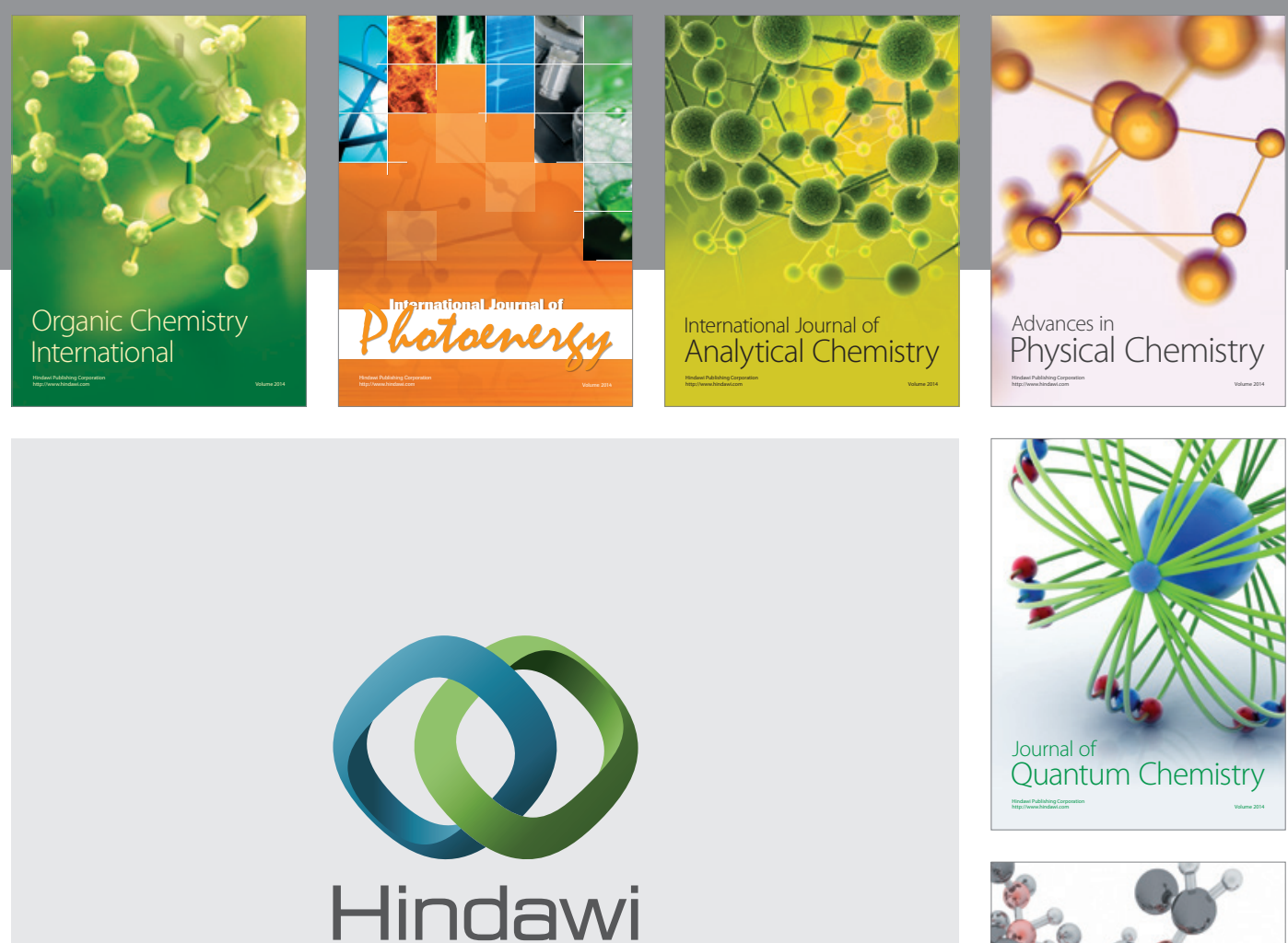

Submit your manuscripts at

http://www.hindawi.com

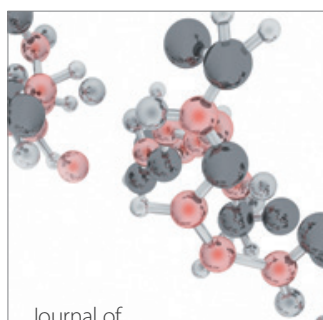

Analytical Methods

in Chemistry

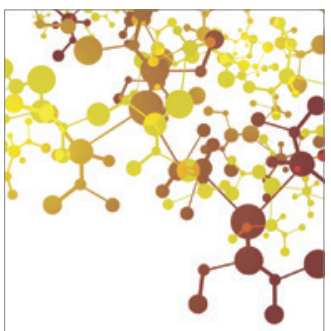

Journal of

Applied Chemistry

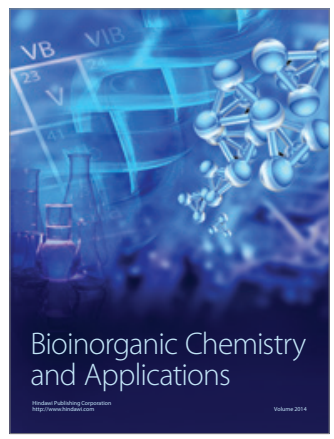

Inorganic Chemistry
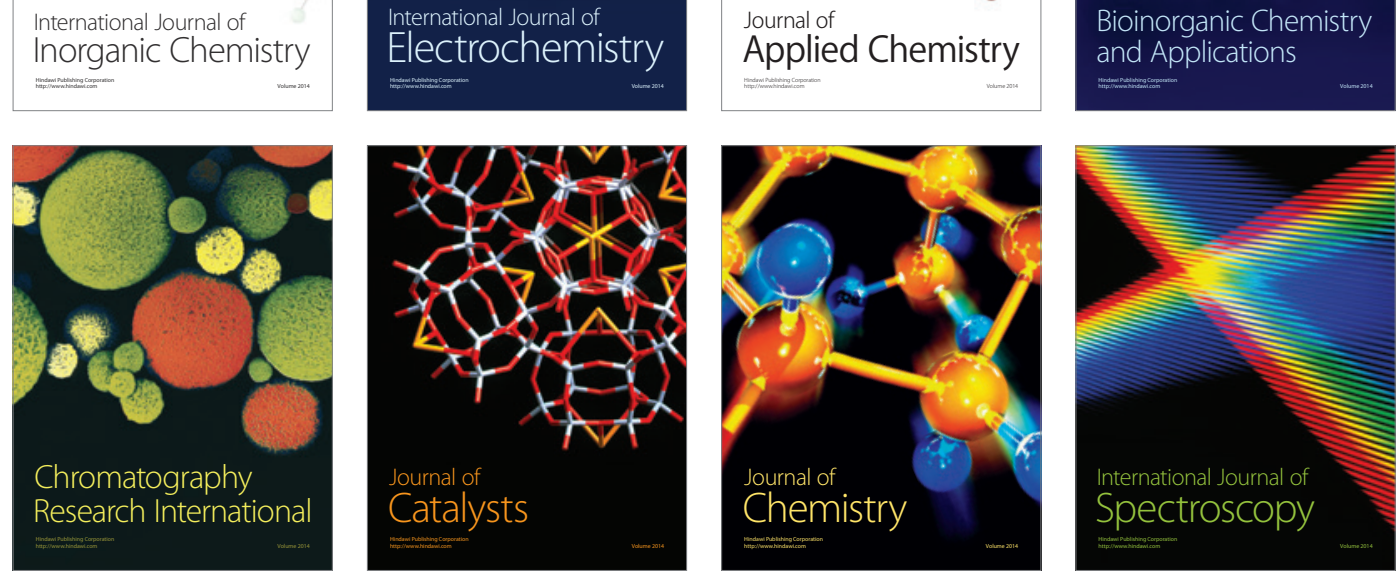